\title{
The Students' Instructional Feedback; A Tool to Improve Lecturer's Teaching Performance
}

\author{
Nenden Sri Fujiya", Ida RahmahAndansari, Ely Widayati, Bambang Widi Pratolo \\ Department of English Education, Postgraduate Program, Universitas Ahmad Dahlan, Indonesia
}

Received February 29, 2020; Revised April 15, 2020; Accepted April 27, 2020

Copyright $\odot 2020$ by authors, all rights reserved. Authors agree that this article remains permanently open access under the terms of the Creative Commons Attribution License 4.0 International License

\begin{abstract}
An educational change agent is an individual who can bring about positive, lasting change for the students that they teach. All students and teachers are learning about the process of change and the role of change agents. During practical teaching and learning, students feedback is an effective tool to be used for the teachers reflection that can be used by Edmodo. The purpose of this study was to explore the students' instructional feedback toward the lecturer teaching performance. To gain the data, the researchers employed a qualitative case study design. The data collected in this study were in the forms of documentation, interview and questionnaire. The participants were 10 students from a private university in Ciamis. The collected data were analyzed by descriptive analysis of feedback, semi structured interview, and questionnaire. As a result, students provided different kinds of feedback to the lecturer. The findings revealed that the lecturer improved the teaching by trying to find a suitable teaching and learning strategy based on students' needs in many ways. It was concluded that students' instructional feedback could help the lecturer to improve teaching. This study suggests that the students and lecturers should be wise enough to apply feedback to identify and rectify their mistakes in teaching and learning process.
\end{abstract}

Keywords Edmodo, Case Study Reflection, Students' Instructional Feedback

\section{Introduction}

Teachers or educators as the agents of change have an opportunity to implement their teaching practices to the best of their ability. During daily activities, Reflection plays an especially important role in the day to day living activities. Whenever you do an event, you could go through a thinking process to focus on the experience either during or after the activity has ended [1]. Further, Reflective teaching is beneficial for the growth of qualified teachers by enabling teachers to look at different viewpoints and ways to approach the classroom and children based on evaluation results [2].

Further, feedback can be given in several ways, for example, from the teacher, the other students, the parents and even each person [3]. Therefore, depending on the source, feedback influences students' self-evaluation differently [4]-[6]. In line with this, the researchers have an understanding that students' feedback is an effective tool to be used as the teachers' reflection because their classroom actions can be well documented and eventually control teachers' future action. On the other hand, it gives the teachers more time to explore what they believed to be considered in detailed analysis [7].

One of feedback to improve lecturer performance is to use student instructional feedback. Student instructional feedback is a practical strategy for monitoring the learning performance provided by lecturers that aims to provide encouragement to teachers to confirm, repair, and improve lecturers learning performance. This feedback is very important for lecturers, students and for performance improvement. Providing appropriate feedback to educators will have a significant impact on their achievement. Feedback plays the best role if it is corrective. This can help lecturers realize their mistakes and learn to correct them by providing informative and explicit feedback when discussing student-centered practices. Therefore, the lecturers should be wise enough to use students' feedback to identify and rectify their mistakes in teaching English. Moreover, the teachers should be wise enough to use students' feedback to identify and rectify their mistakes in teaching English.

The efforts to improve the quality of education in the process of teaching English have been done by many teachers. One such effort is to utilize the media. There are many ways to reflect teaching through media. Learning support media commonly used by teachers is Edmodo. Edmodo is one of the social networks for teachers and 
students that can be applied in teaching English. Edmodo is widely used as online learning or e-learning. In congruent with this, the e-learning are frequently used at various stages of the institutional educational processes; E-learning includes all the educational situations delivered through communication and information technology [8]. Learning through edmodo is very good and also memorable because it enables students to foster the new knowledge which is useful for themselves and others. The role of Edmodo can be used as a virtual class in order to communicate each other between students and teacher through online learning. In line with this, this study used edmodo as a tool to facilitate students in sending their feedback.

Previously, there are some researchers who have conducted their studies related to the present topic. For instance Iqbal[9] conducted a study which entitled "Students' Feedback: A Stimulus Reflective Practice for Professional Development of the Prospective Teachers". Her study portrays students' feedback as an important source of reflection for student teachers. The researcher believes that student's feedback can facilitate teachers to take the responsibility of their own professional development. The second researchers is Albaiz[10]. He conducted a study which entitled 'Effect of Students' Feedback on Teachers' Instructional Practices of EFL Student Teachers". There searchers found that the students were very concerned about the basics of their learning experiences such as highlighting some issues related to teacher performance and strategies to improve learning. Students feedback concentrate on good and polite teacher behavior, learning environment, learning tools and students expect the teacher to act fairly towards all students. The third, previous research study that is conducted by Masantiah[3], with the title "Student and feedback: Which type of feedback is preferable". This research is about comparing the ability of participants with different levels of ability and different types of input to overcome genetic problems. The type of feedback strongly influences students with different levels of ability. The researchers argue that the type of feedback makes a big difference for each group of students. Fourth, Rossiter [11]. He conducted a study with entitled "using an understanding of feedback processes to improve student learning". The researcher found that the role of staff in providing feedback is relatively small, so learning becomes ineffective. But, the classic control loop feedback analysis provides a good representation of the learning process with students. The fifth, Zhang [12]. He conducted a study with entitled "student engagement with teacher and automated feedback on L2 writing". The results of the previous studies indicate that feedback from students could enhance the educators' teaching performance. The researchers believe that the students are real critics for their lecturers or their teachers. In the classroom situation they should distinguish objectively between their teacher's beneficial and unacceptable behaviours. Psychologically, it is also important because teachers are qualified to teach students.

Nevertheless, from the aforementioned study, there are no studies which integrate the feedback of the students with an instructional course. Further, there's no study that used Edmodo as a tool to facilitate students in giving feedback. The researchers are interested in students' instructional feedback as a tool in improving teaching. Moreover, this study focused on the types of feedback do the students give towards learning process of Literature for Language Education and how does the lecturer improve the teaching based on the feedback.

\section{Materials and Methods}

\subsection{Research Design}

The purpose of this study was to explore the students' instructional feedback toward the lecturer teaching performance. In this study, the researchers used the qualitative method. Then, there were three instruments which were conducted to collect the data, namely documentation, interview and questionnaire. Documentation was used to know the students' experiences during teaching and learning activities in the classroom. It was called documentation because the data were taken from Edmodo application. The students updated their experiences after every instructional meeting. Edmodo was an online learning application that is used by the lecturer to support her instructional out of the class and to know students' feedbacks related to her teaching in classroom activities. Then, the interview was used to explore the lecturer responses of the students' feedback about her instruction. In term of the interview's type, the researcher chose individual semi-structured interview consisting of 5 questions which was divided into 3 themes. Whereas, the questionnaire was shared to her students to confirm the lecturers' answers during interview phase and take the students' suggestion so that teaching and learning activities can be hopefully enhanced. Besides, the questionnaire included 10 closed questions with five likert scale (strongly agree, agree, neutral, disagree, and strongly disagree).

\subsection{Research Participant}

This study took 10 students and one lecturer who come from English education program in one of the private university in Ciamis regency, West Java Province, Republic of Indonesia. They were a study group who were learning Literature for Language Education subject. The researchers want to know the students' feedback of their lecturer's teaching performance in order to enhance the English learning quality, particularly in her subject. Besides, one lecturer who was teaching in this subject. As the complete requirement determined by the researcher that 
was enhancing the specific subject quality, this selected using the purposive non-random sampling method.

\subsection{Data Analysis}

In this study, the results of students' feedback would be analysed one by one. Further, the result of feedback from documentation in Edmodo application categorized into several types of feedback, such as positive, descriptive, and neutral feedback[13]-[16].After that, the researchers conducted personal interview to know the lecturer responses of students' feedback who were submitted in edmodo application. The interview is conducted by recording and then transcribed the responses[17].

In analysing the results of the interview session, the researchers formulated the following steps. First, the data from recording were transcribed. Transcripts provided written sources. It was aimed to analyse the data easily. Second, the researcher described the data and then categorize or develop themes[17]. In this study, the researcher used semi-structured interview because the researcher wants to know the specific information and get many advantages from the lecturer's perception.

Furthermore, the researcher analysed the result of questionnaire, the researchers used percentage calculation. Those answers were presented in the form of frequency observed. After she had calculated the frequency of each option, then she computed it into percentage calculation by using formula by Hatch and Farhady[18] as follows:

$$
\mathrm{P}=\frac{F o}{n} \times 100
$$

Note:

$\mathrm{P}=$ Percentage of each category

Fo $=$ frequency of paricipants

$\mathrm{n}=$ the number of sample

\section{Findings and Discussion}

This study concerned to the EFL students' feedback in terms of the teaching performance of their teachers and the effect of these feedback releases on teachers' instructional practices. The aim of this study was therefore to explore the students' instructional feedback toward the lecturer teaching performance. As a result, the researcher inferred several points. First of all, different kinds of feedback given by the students had been found. Overall, they tended to use positive feedback. Secondly, the lecturer tried to find the strategies learning to improve her teaching based on students' need in many ways. Thirdly, the researcher found that the students' response positively towards how the lecturer teaches them after they give their feedback.

To answer the first research question, the researchers categorized three different themes for every feedback that was given by the students. Those themes namely Appreciation to the lecturer and showing support,
Suggestion to improve lecturer's teaching performance, Neutral (did not give a comment for what the lecturer have done in the class). Meanwhile, to answer the second research question, the researchers also proposed several themes such as providing positive feedback to improve teaching performance, matching learning strategies with English students' need, and the significance of students' feedback.

\subsection{What Types of Feedback Do the Students Give towards the Learning Process of Literature for Language Education?}

In answering the first research question, the researchers would describe the types of feedback that the students give to the lecturer by attaching the sentences from the data of students' feedback. There were 3 questions that should be answered by the students in the Edmodo, "What do you think the lecturer's greatest strength is?", "What advice would you give to improve the teaching of this lecturer?" and "Please describe the ways this lecturer has most influenced your learning". Moreover, the researchers categorized three different themes for every feedback that was given by the students. The participants' names were not included but they were only named student 1 up to student 10 .

\subsection{Appreciation to the Lecturer and Showing Support}

Eight students reported that the lecturer has great strength in her teaching and gives them a clear instruction, With regard to this issue, student 1 said "the lecturer provides direction in assigning task, the lecturer has most influenced his/her learning by always giving stimulus by way of speech". Similarly, student 2 said "the lecturer explains material briefly and understandably". Same as the participant before, the third participant, student 3 said "the lecturer always makes the students have a critical thinking during learning process. Further, other participants, student 4, 5 and 6 answered "the lecturer explains material with simple and clear way, the lecturer is very firm and easy to understand in explaining a material." Besides, the student 8 , 9 and 10 answered "the lecturer is a critical teacher, so it made the students learned from her and when the lecturer asked the questions she always let the students answered by their understanding. In addition, the lecturer always provides stimulus and inspiration during teaching and learning".

Thus, this finding means nine students reported that the lecturer has great strength in her teaching and gives them a clear instruction, thus they understand where the course will bring. This statement related to the appreciate someone and gave some motivations as Losada [13] said. The implication of this finding is that feedback is seen as a vital link between the theory that supports teaching and the focus of development of academics in dialogue with 
their students.

\subsection{Suggestion to Improve Lecturer's Teaching Performance}

Within this theme, the researchers identified that there should be something to be improved toward the lecturer's teaching performance. Actually, it should be based on students' need. In congruent with this theme, the students 1 stated "The lecturer should be more conceptual in giving material". With a similar vein, the second participant stated "the lecturer should use different techniques and use some learning approaches, moreover the lecturer should give the assignment to practice the material". Likewise, student 3 said "the lecturer should keep encouraging students to provide motivation and she should assign the task for every topic that they have learned". Moreover, student 4 commented "the lecturer should use different techniques or method of teaching learning and the lecturer should give the assignment to practice the material besides understanding material, practice is also an important thing". Another participant, student 5 and 6 answered "she/he wants the lecturer create the lesson more have fun and colourful". Moreover, student 8 reflected "sometime the lecturer gives a little explanation about the material, it will be better if the lecturer give more explanation for the students. Meanwhile, the lecturer should give another way in delivering material in order to influence the learning to be better such as let students to find out the material, so they can learn by their experience. Lastly, the student 9 and 10 hoped "she wants the lecturer also provide an explanation how to be a good teacher in delivering presentation, so that the students can see the example from the lecturer".

Thus, this finding means the result of all students' feedback contained suggestion for improving lecturer's teaching. As they wish, they need their teaching and learning process to have some various techniques in order that the classroom activities will be as attractive as possible. Further, the implication of this finding is that the feedback has frequently been identified as a key strategy in learning and teaching to do reflection for teaching better in the future.

\subsection{Neutral (Did Not Give a Comment for What the Lecturer Have Done in the Class)}

Different from the other participants, the student $7 \mathrm{did}$ not answer anything for the whole question.

In brief, it is possible to say the results of this study that different kinds of feedback have been found were given by the students. Based on the result of each theme, it can be divided into three types of feedback that the students give towards learning process. On the theme of appreciation of the lecturer and showing support, the researchers categorized it into the type of positive feedback. In relevant with the theory of positive feedback, Losada[13] stated that if the speaker or the writer showed support, encouragement or appreciation (e.g. "That's a good idea") comments could be classified as positive feedback. Further, Dijk[14] demonstrated that positive feedback enhances motivation for a task that people "want," and decrease motivation for a job that people "have to do" relative to negative feedback. Moreover, positive feedback is constructive narrative or explanation of personal behaviour in order to encourage students to show their desired behaviour [3]. In congruent with this theory, the students tended to use positive feedback in giving their feedback such as by writing "the lecturer always provide stimulus and inspiration to learn", "the lecturer is a critical teacher and she always let the students chance to think critically" and "the lecturer gives and explains the material in simple and clear way.

Meanwhile, on the second theme, the researchers found that the students gave descriptive feedback for the lecturer. As Chua [15] said that in comparison with one grade or ranking, descriptive feedback has been found to provide guidance for improving learning. This encourages trust in the mission itself and thus can boost the learning performance and attitudes of students significantly. Moreover, descriptive feedback means giving information and written comments or interactions that allow learners to understand what they need to do in order to improve their level of knowledge [19]. In constituent with the theories aforementioned, the students have answered by written "the lecturer should be more conceptual in giving material". "the lecturer should keep to encourage students to provide motivation". "the lecturer should use different techniques or method of teaching learning, etc.".

For the third theme, the researchers categorized it into neutral feedback. In line with this, neutral feedback is a type of feedback in the form of a response or a response that does not provide meaning or interpretation, so it does not affect the performance of someone being assessed [16]. In other words neutral feedback is an unclear feedback; whether it is positive or negative. The result of feedback showed that the student did not answer anything for all the questions.

From the whole responses of feedback that were given by students, those are very essential for the lecturer to reflect her teaching performance to be better based on students need. As Saylag[20] stated doing a reflection in the practice of teaching, the educator will know how much he/she gets and takes action from students, and so that he/she has a big impact on class management now. Thus, feedback is essential in improving and developing the required learners' knowledge and skills. It also increases student and teacher learning and performance [21]. Such reflection would allow teachers to recognize how their work can be enhanced to improve the quality of learning for pupils [22]. Feedback is therefore an important factor in encouraging learning. 


\subsection{How Does the Lecturer Improve Teaching after Getting Students' Feedback?}

This result showed the lecturer perception toward her experiences and knowledge dealing with importance of students' feedback. The data from semi-structured interviews showed 3 themes. The first theme is providing the positive feedback to improve teaching performance, the second is about matching learning strategies with English students' need. The last but not least is about the significance of students' feedback.

Theme 1: Providing Positive Feedback to Improve Teaching Performance

When the researchers asked the lecturer on how she responds toward different students' need, she answered

"I will teach them based on the situation of class. I try to find some techniques of teaching that cover all students' need, further I will use some learning approaches to get students' attention from their different needs".

The lecturer thinks that students' feedback is very essential to evaluate and to improve teaching regarding to their hope and their expectation. Therefore, it is a system in which teachers reflect on their teaching practices, evaluate how challenges are for students, and how they can strengthen training or to better learning based on different needs of students. In constituent with this, Mirzaei[23] stated that teachers or lecturers are using these reflective skills to develop reflection during their teaching processes.

Theme 2: Matching Learning Strategies with English Students' Need

The second question, the researchers interviewed about the lecturer's strategies learning to improve teaching based on students' need. In answering that question, the lecturer's responded

"I try to find the strategies based on the students need in many ways, for example I provide highlighted material, I find text written in lower level".

Dealing with learning strategy, it is an individual's way of organizing and using a particular set of skills in order to learn content or accomplish other tasks more effectively and efficiently in school as well as in nonacademic settings [24]. Therefore, teachers who teach learning strategies teach students how to learn, rather than teaching them specific curriculum content or specific skills. Thus, regarding to the statement of the lecturer's interview, she used text written and material highlighted to share the strategies and other insights about how the students learned. Teachers can help students apply this strategy by helping them to create material more conceptual as the students' wished and wrote in giving feedback. The main objective of reflective teacher education was therefore to learn why teachers use such teaching methods and how teaching was improved to influence their students positively. Soisangwan [2]stated that reflective teaching is productive for the development of qualified teachers by enabling the teacher to look at ways of handling the classroom and children in different ways based on appraisal results.

\section{Theme 3: The Significance of Students' Feedback}

The last, the researchers categorized the question into the significance of students' feedback for Literature for Language Education subject. That question congruent with the course of the lecturer taught. Moreover, she stated

"It makes the learning more interesting because I know what the students want and what the students need in learning Literature for Language Education"

Thus, reflection is an important technique for teachers to evaluate and develop their teaching practices [22]. Furthermore, in congruent with this, Masantiah[25] stated that in self-assessment, students play an important role to detect their own strengths and weaknesses, so feedback is an instrument for increasing the self-assessed precision of the students.

Furthermore, to support and to recheck the data of interview, the researchers administered questionnaire from the students' who were taught by the lecturer. This data aimed to show whether the lecturer really improved teaching or not. In collecting the data, the researchers used likert scale questionnaire. The questionnaires consist of 10 questions. The data showed 5 different responses of students namely strongly agree, agree, neutral, disagree, and strongly disagree scale.

Further, the examination of the data showed that the lecturer improved teaching based on students' needs after getting student's feedback. It is proved by the answer of the students who stated $10 \%$ "strongly agree", $40 \%$ agree and neutral " $50 \%$ ". The students stated strongly agree $(10 \%)$, agree $(50 \%)$, neutral $(20 \%)$ and disagree $(20 \%)$ that the lecturer managed classroom time and pace well. Moreover, $10 \%$ students stated strongly agree and $50 \%$ students agree, $20 \%$ neutral and $20 \%$ disagree that the lecturer was organized and prepared for every class. In addition, $40 \%$ students stated strongly agree, $30 \%$ agree and $30 \%$ neutral in assuming that the lecturer encouraged discussions and responded to questions. However, $10 \%$ students stated strongly agree, $40 \%$ agree, $20 \%$ neutral and $30 \%$ disagree that the lecturer demonstrated the subject in depth-knowledge. 


\begin{tabular}{|c|c|c|c|}
\hline No. & Questionnaires' Points & Percentage (\%) & Meaning \\
\hline \multirow{5}{*}{ Q1 } & \multirow{5}{*}{ The lecturer stimulated my interest in the subject } & $10 \%$ & Strongly Agree \\
\hline & & $40 \%$ & Agree \\
\hline & & $50 \%$ & Neutral \\
\hline & & $0 \%$ & Disagree \\
\hline & & $0 \%$ & Strongly Disagree \\
\hline \multirow{5}{*}{ Q2 } & \multirow{5}{*}{ The lecturer managed classroom time and pace well } & $10 \%$ & Strongly Agree \\
\hline & & $50 \%$ & Agree \\
\hline & & $20 \%$ & Neutral \\
\hline & & $20 \%$ & Disagree \\
\hline & & $0 \%$ & Strongly Disagree \\
\hline \multirow{5}{*}{ Q3 } & \multirow{5}{*}{$\begin{array}{l}\text { The lecturer was organized and prepared for every } \\
\text { class }\end{array}$} & $10 \%$ & Strongly Agree \\
\hline & & $50 \%$ & Agree \\
\hline & & $20 \%$ & Neutral \\
\hline & & $20 \%$ & Disagree \\
\hline & & $0 \%$ & Strongly Disagree \\
\hline \multirow{5}{*}{ Q4 } & \multirow{5}{*}{$\begin{array}{l}\text { The lecturer encouraged discussions and responded to } \\
\text { questions }\end{array}$} & $40 \%$ & Strongly Agree \\
\hline & & $30 \%$ & Agree \\
\hline & & $30 \%$ & Neutral \\
\hline & & $0 \%$ & Disagree \\
\hline & & $0 \%$ & Strongly Disagree \\
\hline \multirow{5}{*}{ Q5 } & \multirow{5}{*}{$\begin{array}{l}\text { The lecturer demonstrated in depth-knowledge of the } \\
\text { subject }\end{array}$} & $10 \%$ & Strongly Agree \\
\hline & & $40 \%$ & Agree \\
\hline & & $20 \%$ & Neutral \\
\hline & & $30 \%$ & Disagree \\
\hline & & $0 \%$ & Strongly Disagree \\
\hline \multirow{5}{*}{ Q6 } & \multirow{5}{*}{$\begin{array}{l}\text { The lecturer used a variety of instructional methods to } \\
\text { reach the course objectives (e.g. group, discussions, } \\
\text { student presentations, etc.) }\end{array}$} & $20 \%$ & Strongly Agree \\
\hline & & $20 \%$ & Agree \\
\hline & & $60 \%$ & Neutral \\
\hline & & $0 \%$ & Disagree \\
\hline & & $0 \%$ & Strongly Disagree \\
\hline \multirow{5}{*}{ Q7 } & \multirow{5}{*}{ The lecturer challenged students to do their best work } & $10 \%$ & Strongly Agree \\
\hline & & $50 \%$ & Agree \\
\hline & & $30 \%$ & Neutral \\
\hline & & $10 \%$ & Disagree \\
\hline & & $0 \%$ & Strongly Disagree \\
\hline \multirow{5}{*}{ Q8 } & \multirow{5}{*}{ The lecturer was accessible outside of class } & $30 \%$ & Strongly Agree \\
\hline & & $50 \%$ & Agree \\
\hline & & $20 \%$ & Neutral \\
\hline & & $0 \%$ & Disagree \\
\hline & & $0 \%$ & Strongly Disagree \\
\hline \multirow{5}{*}{ Q9 } & \multirow{5}{*}{$\begin{array}{l}\text { Information about the assessment was communicated } \\
\text { clearly }\end{array}$} & $10 \%$ & Strongly Agree \\
\hline & & $50 \%$ & Agree \\
\hline & & $20 \%$ & Neutral \\
\hline & & $20 \%$ & Disagree \\
\hline & & $0 \%$ & Strongly Disagree \\
\hline \multirow{5}{*}{ Q10 } & \multirow{5}{*}{$\begin{array}{l}\text { Students' feedback showed how to improve lecturer's } \\
\text { work (e.g corrections including comments). }\end{array}$} & $20 \%$ & Strongly Agree \\
\hline & & $30 \%$ & Agree \\
\hline & & $50 \%$ & Neutral \\
\hline & & $0 \%$ & Disagree \\
\hline & & $0 \%$ & Strongly Disagree \\
\hline
\end{tabular}


Related to the result of students' response , $20 \%$ students stated strongly agree, $20 \%$ students decided to choose agree, and $60 \%$ neutral that the lecturer employed a number of methods for following the goals of the course (e.g. party, meetings, student lectures, etc.). Further, $10 \%$ students stated strongly agree, $50 \%$ agree, $30 \%$ neutral and $10 \%$ disagree that the lecturer challenged students to do their best work. Besides, $30 \%$ students out of 10 students stated strongly agree, $50 \%$ agree, and $20 \%$ neutral that lecturer was accessible outside of class. In line with this, the lecturer delivered the information about the assessment and it was communicated clearly, it's proved by the students' agreement in $10 \%$ and $50 \%, 20 \%$ neutral and $20 \%$ disagree. Finally, the students feel that feedback showed how to improve their work (e.g. corrections including comments), they stated strongly agree $20 \%, 30 \%$ agree, and $50 \%$ neutral for the statement. Furthermore, giving feedback in Literature for Language Education course can be used to improve and evaluate the teaching and learning process by the lecturer such as making a strategy learning, etc. In this context, Astika [26] mentioned reflective teaching is particularly important if it involves human contact such as teacher-student communication in the classroom during learning process. Moreover, Masantiah [3] showed a different level of feedback for students with different comprehensive skills and basic knowledge. The feedback was nonetheless helpful to all. The learning effectiveness of students after feedback has also improved considerably in [27], [28].

Finally, from the result of semi structured interview and the students' questionnaire, the lecturer actually improved teaching based on different students' need. It is proved by the suitability result of interview data and students' questionnaire. In the result of interview the lecturer stated that she will teach her students based on the situation of class. She tried to find some techniques of teaching that cover all students' need, further she will use some learning approaches to get students' attention from their different needs". Furthermore, the lecturer also stated that she tried to find the strategies based on the students need in many ways, for example she provided highlighted material, she found text written in lower level. Thus, in this field the lecturer has improved her teaching related to the classroom management and teaching learning improvement. As supported by Semley, N [29] stated that more specifically, the process of learning development in strategy learning can include students as self-directed learners, and acknowledge the learning material that lecturers utilise to support learning. In this context, the role of feedback in the Learning Development process is to inform a student about their current level of understanding and to guide them for future assessments through their experience. Moreover, Feed forward provides candidates with explicit instructions on how to improve their performance, instead of only giving a commentary on what has been done [30].

Meanwhile, the result of questionnaire proved that the lecturer doing reflection in improving teaching and learning process. It showed from the questions in the questionnaire data that most of students agreed the lecturer managed classroom time and pace well. Same as the previous question, $50 \%$ of 10 students agreed that the lecturer was organized and prepared for every class. Moreover, most of the student answered that the lecturer encouraged discussions and responded to questions and the lecturer challenged students to do their best work. Dealing with this, according to C. Paterson, N. Paterson, and W. Jackson [31] assumed that Feedback is a fundamental factor within the learning process for students. Evidence underscores that effective feedback on students' performance from assessments can be a front-runner to improve learning outcomes [32]. Feedback, combined with effective instruction, can have a powerful influence on accelerating students' learning [13].

In general, the implications of this study were twofold namely theoretically and practically. In theoretical part, this study has therefore increased our understanding of the meaning of effective feedback \& the role of students' feedback in instructional course. Meanwhile, practically this study is very beneficial for educators and for students on student learning and progress through a course of study.

\section{Conclusions}

Dealing with the result and discussion aforementioned, it can be concluded that most of students gave positive feedback and descriptive feedback for the lecturer. There are three types of feedback that the students give towards learning process of Literature for Language Education subject. They are positive feedback, neutral feedback and descriptive feedback. It was found through the data that the lecturer tried to find the learning strategies to improve her teaching based on students' need in many ways, such as providing highlighted material, and she found text written in lower level. Furthermore, the researchers found out that the lecturer improved her teaching after getting feedback because most of students agreed if the lecturer do so. They response positively on how the lecturer teaches them.

\section{Acknowledgments}

Firstly, we would like to thank for the lecturer in providing the opportunity to develop research and give more support until this research is completed. Then, we would like to say thank you for the lecturer who teaches Literature for Language Education subject and to the students of 3B in English Department who have been being participant in this study. Finally, we would like to say thank you for Galuh University for allowing us to conduct the research. 


\section{REFERENCES}

[1] H. S. Afshar and M. Farahani, "Reflective Thinking and Reflective Teaching among Iranian EFL Teachers: Do Gender and Teaching Experience Make a Difference?," Procedia - Soc. Behav. Sci., vol. 192, pp. 615-620, 2015, doi: 10.1016/j.sbspro.2015.06.107.

[2] A. Soisangwarn and S. Wongwanich, "Promoting the Reflective Teacher through Peer Coaching to Improve Teaching Skills," Procedia - Soc. Behav. Sci., vol. 116, pp. 2504-2511, 2014, doi: 10.1016/j.sbspro.2014.01.601.

[3] C. Masantiah, S. Pasiphol, and K. Tangdhanakanond, "Student and feedback: Which type of feedback is preferable?" Kasetsart J. Soc. Sci., pp. 1-6, 2018, doi: 10.1016/j.kjss.2018.07.020.

[4] S. Klaimanee and I. Sonthipumas, "THE DEVELOPMENT OF HEALTH CARE MODEL AMONG NURSING STUDENTS AT BOROMARAJONANI COLLEGE OF," pp. 83-96, 2018.

[5] F. M. Van Der Kleij, T. J. H. M. Eggen, C. F. Timmers, and B. P. Veldkamp, "Effects of feedback in a computer-based assessment for learning," Comput. Educ., vol. 58, no. 1, pp. 263-272, 2012, doi: 10.1016/j.compedu.2011.07.020.

[6] G. Ç. Yastıbaș and A. E. Yastıbaș, "The Effect of Peer Feedback on Writing Anxiety in Turkish EFL (English as a Foreign Language) Students," Procedia - Soc. Behav. Sci., vol. 199, pp. 530-538, 2015, doi:10.1016/j.sbspro.2015.07 .543 .

[7] T. Farrell, "Understanding Reflective Teaching," Teach. Learn., vol. 19, no. 2, pp. 52-63, 2013.

[8] O. Dodun et al., "Analysis of an E-learning Platform use by Means of the Axiomatic Design," Procedia CIRP, vol. 34, pp. 244-249, 2015, doi: 10.1016/j.procir.2015.07.059.

[9] M. Z. Iqbal, M. Ramzan, and A. A. Arain, "Students' Feedback: A Stimulus Reflective Practice for Professional Development of the Prospective Teachers," J. Res. Reflections Educ., vol. 10, no. 1, pp. 69-79, 2016, [Online]. Available: http://www.ue.edu.pk/jrre.

[10] T. Albaiz, "EFFECT OF STUDENTS' FEEDBACK ON TEACHERS' INSTRUCTIONAL PRACTICES OF EFL STUDENT TEACHERS," vol. 1, no. 5, pp. 31-43, 2012.

[11] J. A. Rossiter, "Using an understanding of feedback processes to improve student learning," IFAC-Papers OnLine, vol. 49, no. 6, pp. 57-62, 2016, doi: 10.1016/j.ifac ol.2016.07.153.

[12] Z. (Victor) Zhang and K. Hyland, "Student engagement with teacher and automated feedback on L2 writing," Assess. Writ., vol. 36, no. March, pp. 90-102, 2018, doi: 10.1016/j .asw.2018.02.004.

[13] M. Losada and E. Heaphy, "The Role of Positivity and Connectivity in the Performance of Business Teams: A Nonlinear Dynamics Model," Am. Behav. Sci., vol. 47, no. 6, pp. 740-765, 2004, doi: 10.1177/0002764203260208.

[14] D. Van Dijk and A. N. Kluger, "Task Type as a Moderator of
Positive/Negative Feedback Effects on Motivation and Performance: A regulatory focus perspective," J. Organ. Behav., vol. 32, no. 8, pp. 1084-1105, 2011, doi: 10.1002/j ob.

[15] H. L. Chua, S. H. Lee, and G. W. Fulmer, "Action research on the effect of descriptive and evaluative feedback order on student learning in a specialized mathematics and science secondary school," 2017, doi: 10.1186/s41029-017 $-0015-y$.

[16] A. Rachmiatie, "“Feedback' terhadap Layanan dan Aturan Pemerintah : Sebuah Studi Kasus," Mediator, vol. 3, no. 3, pp. 323-338, 2002.

[17] J. W. Creswell, Educational research: Planning, conducting, and evaluating quantitative and qualitative research, vol. 4. 2012.

[18] "Research_design_and_statistics_for_appli.pdf."

[19] P. Sachse-Brown and J. Aldridge, "Suggested Next Steps re : Descriptive Feedback and Some Strategies," 2004.

[20] R. Saylag, "Self Reflection on the Teaching Practice of English as a Second Language: Becoming the Critically Reflective Teacher," Procedia - Soc. Behav. Sci., vol. 46, pp. 3847-3851, 2012, doi: 10.1016/j.sbspro.2012.06.158.

[21] S. Panhoon and S. Wongwanich, "An Analysis of Teacher Feedback for Improving Teaching Quality in Primary Schools," Procedia - Soc. Behav. Sci., vol. 116, pp. 4124 4130, 2014, doi: 10.1016/j.sbspro.2014.01.902.

[22] H. Fatemipour, "The Efficiency of the Tools Used for Reflective Teaching in ESL Contexts," Procedia - Soc. Behav. Sci., vol. 93, pp. 1398-1403, 2013, doi: 10.1016/j.sbspro.2013.10.051.

[23] F. Mirzaei, F. A. Phang, and H. Kashefi, "Measuring Teachers Reflective Thinking Skills," Procedia - Soc. Behav. Sci., vol. 141, pp. 640-647, 2014, doi: 10.1016/j.sb spro.2014.05.112.

[24] A. M. Sunbul, "an Analysis of High School Students' Learning Strategies and an Analysis of High School Students' Learning," no. June 2004, 2016.

[25] C. Masantiah, S. Pasiphol, and K. Tangdhanakanond, "Kasetsart Journal of Social Sciences Student and feedback: Which type of feedback is preferable?" Kasetsart J. Soc. Sci., pp. 1-6, 2018, doi: 10.1016/j.kjss.2018.07.020.

[26] G. Astika and U. K. Satya Wacana, "Reflective Teaching as Alternative Assessment in Teacher Education: a Case Study of Pre-Service Teachers," TEFLIN J. A Publ. Teach. Learn. English, vol. 25, no. 1, pp. 16-32, 2014, doi: 10.15639/TE FLINJOURNAL.V25I1/16-32.

[27] Y. Attali, "Effects of multiple-try feedback and question type during mathematics problem solving on performance in similar problems," Comput. Educ., vol. 86, pp. 260-267, 2015, doi: 10.1016/j.compedu.2015.08.011.

[28] Y. Attali, "Immediate feedback and opportunity to revise answers: Application of a graded response IRT model," Appl. Psychol. Meas., vol. 35, no. 6, pp. 472-479, 2011, doi: $10.1177 / 0146621610381755$.

[29] N. Semley, R. Huang, and J. Dalton, "Leisure, Sport \& Tourism Education Feedback for Learning Development: 
Tourism students' perspective," J. Hosp. Leis. Sport Tour. Educ., vol. 19, pp. 41-53, 2016, doi: 10.1016/j.jhlste.2016. 08.001 .

[30] P. Conaghan and A. Lockey, "Feedback to feedforward: A positive approach to improving candidate success," Notfall und Rettungsmedizin, vol. 12, no. SUPP.2, pp. 45-48, 2009 , doi: 10.1007/s10049-009-1222-1.

[31] C. Paterson, N. Paterson, and W. Jackson, "Jo ur 1 P re," Nurse Educ. Today, p. 104236, 2019, doi: 10.1016/j.nedt.2 019.104236.

[32] A. JOHNSON, G. M. \& COOKE, "Running Head: WRITTEN VERSUS AUDIO-RECORDED FEEDBACK Self-regulation of learning and preference for written versus audio-recorded feedback by distance education students," Distance Educ., pp. 107-120., 2016. 